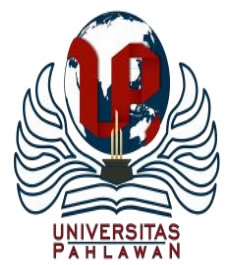

Edukatif : Jurnal Ilmu Pendidikan Volume 3 Nomor 3 Tahun 2021 Halm 631 - 639

EDUKATIF: JURNAL ILMU PENDIDIKAN

Research \& Learning in Education

https://edukatif.org/index.php/edukatif/index

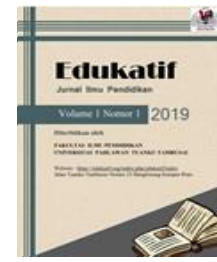

\title{
Implementasi Nilai Dasar Pancasila Dalam Upaya Mewujudkan Tujuan Negara di Kehidupan Sehari-Hari
}

\author{
Mila Andriani Nurcahya ${ }^{1 凶}$, Dinie Anggraeni Dewi² \\ Universitas Pendidikan Indonesia, Bandung, Indonesia ${ }^{\mathbf{1 , 2}}$ \\ E-mail : milaandriani@upi.edu ${ }^{1}$, dinieanggraenidewi@ upi.edu $^{2}$
}

\begin{abstract}
Abstrak
Pancasila merupakan dasar negara yang dapat dijadikan sebagai sumber dari segala sumber hukum, sebagai pedoman dalam mengatur penyelenggaraan pemerintah serta Pancasila dapat dijadikan dasar dalam pelaksanaan pemerintahan. Tujuan penelitian ini adalah untuk memberikan gambaran menganai implementasi dari pancasila yang dapat dilaksanakan dalam kehidupan sehari hari. Metode penelitian yang digunakan adalah kualitatif dengan studi literatur serta menggunakan pendekatan deskriptif. Pada penelitian ini untuk mengumpulkan data diperoleh melalui hasil studi kepustakaan yang bersumber dari jurnal serta artikel. Hasil penelitian yang diperoleh adalah banyak sekali nilai-nilai dari pancasila yang dapat diimplementasikan dalam kehidupan sehari-hari. Salah satunya adalah dengan menjunjung tinggi nilai-nilai keagamaan sesuai dengan agama yang dianut. Senantiasa berperilaku jujur yang sesuai dengan nilai dari Pancasila. Selalu menghormati perbedaan dan memiliki sikap tolansi yang baik agar tercipta sebuah persatuan. Serta dengan selalu berdemokrasi dan memiliki sikap yang adil. Sehingga dengan adanya artikel ini dapat dijadikan sebagai acuan untuk mengimplementasikan pancasila dalam kehidupan sehari-hari.
\end{abstract}

Kata Kunci: Implementasi Pancasila, Nilai Pancasila, Peran Pancasila

\begin{abstract}
Pancasila is national principle of Indonesia which can be used as the source of all sources of law, as a guideline in regulating government administration and Pancasila can be used as the basis of the governance. The purpose of this study is to provide an overview of the implementation of Pancasila which can be implemented in daily life. The research uses qualitative method with literature studies and a descriptive approach. The data was obtained through the results of literature studies from journals and articles. The results obtained show that there are a lot of values of Pancasila that can be implemented in daily life. Some of them are by upholding religious values in accordance with the religion one follow, always behave honestly and in accordance with the values of Pancasila, always respect differences and have good attitude to create unity, and by always being democratic and uphold the justice. So, this article can be used as a reference for implementing Pancasila in daily life.
\end{abstract}

Keywords: Pancasila Implementation, Pancasila Value, The Role of Pancasila

Copyright (c) 2021 Mila Andriani Nurcahya, Dinie Anggraeni Dewi

$\triangle$ Corresponding author

Email : milaandriani@upi.edu

DOI $\quad:$ https://doi.org/10.31004/edukatif.v3i3.411

ISSN 2656-8063 (Media Cetak)

ISSN 2656-8071 (Media Online)

Edukatif : Jurnal Ilmu Pendidikan Vol 3 No 3 Tahun 2021 p-ISSN 2656-8063 e-ISSN 2656-8071 
632 Implementasi Nilai Dasar Pancasila Dalam Upaya Mewujudkan Tujuan Negara di Kehidupan SehariHari-Mila Andriani Nurcahya, Dinie Anggraeni Dewi

DOI: https://doi.org/10.31004/edukatif.v3i3.411

\section{PENDAHULUAN}

Indonesia mempunyai sebuah dasar negara yang skita kenal dengan nama Pancasila. Sumber dasar negara tersebut berasal dari para leluhur bangsa Indonesia. Pancasila memiliki peranan yang penting bagi bangsa Indonesia. Pancasila juga selain menjadi dasar negara merupakan pandangan hidup bangsa Indonesia. Dalam menjalankan kehidupan bernegara Indonesia berpedoman terhadap Pancasila mulai dari sistem pemerintahannya hingga pelaksanaan kehidupan sehari-hari warganya.

Pancasila memiliki lima arti yang sangat dapat diajadikan sebagai pedoman hidup dan landasan hidup bagi bangsa Indonesia. Namun dalam pelaksanaannya banyak sekali masyarakat dan pejabat pemerintah yang melakukan penyimpangan dari nilai-nilai Pancasila. (Situru, 2019) mengatakan bahwa penyimpangan tersebut disebabkan karena adanya ketidakpuasan terhadap produk hukum. Sehingga banyak pejabat negara yang melakukan penyelewangan jabatannya dan melakukan hal-hal yang tidak sesuai dengan norma yang berlaku. Serta terdapat banyak masyarakat yang melanggar dan melakukan penyimpangan seperti adanya penyalahgunaan narboka, melakukan tindakan kriminal, dan lainnya

Adanya penyimpangan tersebut akan menimbulkan berbagai macam pertetantangan dari masyarakat yang dapat menurunkan kepecercayaannya terhadap Pancasila. Namun, hal tersebut dapat kita cegah dengan menjunjung tinggi serta memahami nilai-nilai yang terkandung di dalam Pancasila. Salah satunya yaitu dengan menerapakan nilai Pancasila pada kehidupan sehari-hari. Seperti halnya beberapa tindakan tercela, apabila kita telah menanamkan nilai-nilai Pancasila terhadap diri kita, maka tidak akan membuat kita terjerumus ke dalam beberapa hal yang tidak diinginkan.

Dalam kehidupan sekarang banyak sekali tantangan dalam pengimplementasian Pancasila entah itu tantangan dari dalam diri atau pun tantangan yang berasal dari luar. Tantangan tersebut dapat dijadikan dorongan agar masyarakat Indonesia dapat menjunjung tinggi nilai-nilai dari Pancasila yang sangat memiliki banyak manfaat. Sehingga dengan begitu tantangan yang akan masuk ke dalam akan terhalang karena warga Indonesia sudah memiliki kelekatan pada dasar negaranya yaitu Pancasila (Harefa, 2011).

Dalam Pancasila memiliki nilai positif yang sangat banyak serta dapat dijadikan sebagai pedoman hidup bangsa Indonesia. Namun, dalam kenyataannya masayarakat di Indonesia banyak memahami nilai-nilai yang terkandung dalam pancasila dengan baik. Sehingga saat ini banyak sekali peristiwa yang tidak diinginkan dan menjadi ancaman dalam kehidupan bernegara. Sehingga dengan permasalahan yang telah dipaparkan akan dibahas mengenai implementasi nilai-nilai pancasila pada kehidupan sehari di kalangan masyarakat serta upaya yang dapat dilakukan agar Pancasila dapat terjaga dengan utuh dan berjalan sesuai dengan nilai-nilai Pancasila.

\section{METODE PENELITIAN}

Dalam penelitian ini yaitu menggunakan metode kualitatif dengan pendekatan secara deksriptif. Dalam pengumpulan informasi serta data yang akan dibahas pada penelitian ini, penulis menggunakan studi kepustakaan. Dengan Teknik pengumpulan datanya melakukan studi literatur terhadap buku, literatur-literatur serta jurnal yang sesuai dan berkaitan dengan permasalahan yang diangkat yaitu mengenai implementasi pancasila dalam kehidupan sehari-hari.

Waktu pelaksanaan penelitian ini dilakukan selama 1 bulan dari bulan Maret hingga April 2021. Subjek dari penelitian ini yaitu berupa sumber data yang diperoleh. Dalam penelitian ini memiliki sumber utama yaitu berasal dari buku serta sumber lainnya berasal dari jurnal. Prosedur dalam penelitian ini dilaksanakan melalui duatahap penelitian diantaranya: (1) Tahap Perencanaan, dalam tahap perencanaan ini peneliti melakukan sebuah kajian pustaka yaitu untuk memperoleh berbagai sumber serta beberapa teori yang dapat digunakan sebagai pendukung dalam penelitian ini. (2) Tahap Pelaksanaan, setelah peneliti mendapatkan sumber, 
633 Implementasi Nilai Dasar Pancasila Dalam Upaya Mewujudkan Tujuan Negara di Kehidupan SehariHari-Mila Andriani Nurcahya, Dinie Anggraeni Dewi

DOI: https://doi.org/10.31004/edukatif.v3i3.411

kemudian pada tahap ini peneliti melakukan analisis untuk memperoleh jawaban yang dapat digunakan sebagai kesimpulan dari hasil analisis data.

Pada penelitian ini instrument penelitiannya menggunakan pendekatan kualitatif, instrumen penelitiannya yaitu peneliti. Hal tersebut disebakana karena penelitian kualititaf dapat dijadikan sebagai human instumeent karena telah menetapkan memilih informasi yang dituju sebagai sumber data, fokus penelitian, serta melaksanakan penghimpunan data serta membuat kesimpulan dari hasil penelitian. Teknik pengumpulan data pada penelitian ini dilakukan secara kajian kepustakaan dengan membaca sumber informasi dari buku serta jurnal.

Pada penelitian ini peneliti memilih suatu hal yang dijadikan pokok. Serta mempokuskan terhadap halhal yang penting. Dalam penelitian ini reduksi data dilakukan setelah peneliti selesai memperoleh data dari hasil pengumpulan datanya. Dalam penyajian data peneliti memaparkan pengetahuan yang dimilikinya serta memaparkan dari data yang telah diperoleh dari hasil penelitiannya. Sehingga peneliti dapat menarik kesimpulan dari penelitian ini. Kesimpulan merupakan sebuah hasil dari rangkatan analisis data. Adanya penarikan kesimpulan ini akan memperoleh makna dari data yang telah dipaparkan. Kemudian setelah hasil penelitian peneliti menarik kesimpulan secara keseluruhan.

\section{HASIL DAN PEMBAHASAN PENELITIAN}

Pancasila merupakan dasar negara, pandangan hidup negara serta ideologi Bangsa Indonesia. Dalam Pancasila berisi lima dasar mengenai jati diri bangsa Indonesia. Sila-sila dalam Pancasila itu menggambarkan mengenai pedoman hidup bangsa Indoenesia. Salah satunya adalah peranan Pancasila dalam ketatanegaraan yang bukan hanya sekedar dasar serta tujuan formalitas dari negara. Melainkan Pancasila merupakan sebagai dasar bagi bangsa Indonesia, Falsafah negara, ideologi serta cita-cita negara dan hukum bangsa Indonesia serta sebagai pemersatu masyarakat Indonesia (Darmadi, 2020).

Pancasila selalu hidup di setiap ruang serta waktu dalam kehidupan bernegara dan dalam ketatanegaraan Pancasila memiliki nilai yang mutlak (Bo'a, 2017). Sehingga Pancasila sangat penting dalam keberlangsungannya sistem ketatanegaraan. Selain memiliki peran dalam ketatangeraan Pancasila juga memiliki peranan dalam tatanan keseharian hidup masyarakat. Memiliki arti bahwa Pancasila bukan hanya sekedar ideologi bangsa saja tetapi Pancasila merupakan pedoman yang dapat dijadikan sebagai penuntun serta tujuan hidup bangsa Indonesia. Sehingga dalam kehidupan di masyarakat bahkan keluarga serta negara, mereka berperilaku dan tujuannya berdasarkan Pancasila. Oleh karena itu Pancasila sangat penting dalam kehidupan masyarakat Indonesia.

Adanya kesepakatan consensus membuat sebuah perkembangan yaitu menjadikan pancasila sebagai cita-cita negara serta sebagai filosofishe gronslag. Filosofi ini yang memiliki arti bahwa Pancasila dapat berperan sebagai pandangan hidup bangsa Indonesia. Karena dalam Pancasila tersebut memiliki beberapa kepentingan yang pertama adalah Pancasila diharapkan akan mennjadi pedoman dan petuntjuk dalam kehidupan bangsa Indonesia. Kedua, Pancasila juga dapat menjadi dasar negara yang menyeluruh dalam kegiatan negara seperti halnya pada bidang politik, hukum serta ekonomi dan kegiatan sosial masyarakat (Asshiddiqie, 2010).

Sebelum disempurnakan, Pancasila memiliki lima dasar yang belum tersusun seperti yang sudah ada saat ini. Melainkan, dasar-dasar yang soekarno sebutkan adalah kebangsaan Indonesia, internasionlisme (kemanusiaan), mufakat atau permusyawaratan, kesejahteraan (keadilan sosial) dan ketuhanan. Kebangsaan yang dimaksud Soekarno merupakan Nationale Staat dan nasionalisme Indonesia yang memiliki arti bahwa warga negara Indonesia harus memiliki rasa kesatuan yaitu satu bangsa dan tumpah darah yang sama yaitu Indonesia. Prinsip selanjutnya adalah perikemanusiaan (internasionalisme) ini menjadi penting karena betujuan agar bangsa Indonesia memiliki rasa bagian dari dunia (Dewantara, 2018). 
634 Implementasi Nilai Dasar Pancasila Dalam Upaya Mewujudkan Tujuan Negara di Kehidupan SehariHari - Mila Andriani Nurcahya, Dinie Anggraeni Dewi

DOI: https://doi.org/10.31004/edukatif.v3i3.411

Kemudian permusyawaratan merupakan perjuangan dari seluruh rakyat Indonesia melalui wakil-wakil dengan tujuan kesejahteraan umum masayarakat Indonesia. Selanjutnya adalah kesejahteraan sosial yaitu kemakmuran yang menjadi kewajiban dan harus dinikmati oleh warga Indonesia yang merupakan kepentingan suatu bangsa yang terbentuk. Terkahir adalah ketuhanan yaitu ketuhanan yang berkebudayaan memiliki arti bahwa bangsa indoneisa menghargai setiap pengakuan keberagaman agama-agama yang ada di Indonesia. Dalam Pancasila nilai-nilai yang terkandung di dalamnya dapat kita amalkan serta diimplementasikan dalam kehidupan bermsayakrakat. Tujuannya adalah untuk dapat membangun serta memperbaiki karakter dari bangsa Indonesia. Sehingga Pancasila dapat menjadi bagian pada upaya menghidupkan dapat menjadi karakter yang membudaya dari bangsa Indonesia.

Keberadaan dari pancasila ini dapat kita lihat secara historis dan juga secara kultural. Pancasila dapat dijadikan sebagai pandangan hidup bangsa Indonesia karena sudah ada sebelum bangsa Indonesia terbentuk yang disebut sebagai secara historis. Serta Pancasila ini berkembang melalui beberapa proses sehingga terbentuk suatu bangsa. Sedangkan secara kultural pancasila ini merupakan dasar-dasar dari pemikiran yang asalnya merupakan nilai kebudayaan masayarakat Indonesia dan nilai dari religius (Zabda, 2017). Dengan adanya hal tersebut maka Pancasila merupakan sebuah pegangan yang kuat dari bangsa Indonesia. Selain karena sudah ada sejak zaman nenek moyang Pancasila juga merupakan kewajiban kita untuk dilestarikan. Sehingga akan menjadi nilai yang baik karena kita dapat mengamalkan Pancasila karena merupakan dasar negara bagi bangsa Indonesia yang kita miliki

Implementasi Pancasila merupakan sebuah upaya dalam mengamalkan nilai-nilai yang terdapat pada Pancasila. Pancasila sendiri terdapat lima bahasan pokok yaitu nilai ketuhanan, nilai kemanusiaan, nilai kesatuan, nilai kerakyatan, serta nilai keadilan. Selain menjadi dasar negara, ideologi bangsa, serta pandangan hidup dan Pancasila juga digunakan dalam tatanan kehidupan sehari-hari. Pada kehidupan ini, banyak warga negara yang sudah memahami arti penting dari Pancasila, tetapi ada juga sebagian masyarakat yang kurang memahami pancasila. Sehingga nilai-nilai yang terkandung dalam Pancasila belum banyak tersampaikan secara tepat kepada masyarakat.

Salah satunya adalah saat ini di Indonesia tidak semua masyarakat mengikuti dan menjalankan pendidikan dengan baik. Untuk memahami Pancasila yang dapat kita pelajari dan pahami dalam Pendidikan Kewarganegaraan yang didalamnya terdapat banyak sekali manfaat salah satunya adalah pengembangan karakter. Pendidikan karakter dalam Pendidikan Kewarganegaraan dikembangan dengan cara sistematik serta sistemik (Akbal, 2016). Hal tersebut terdapat kaitannya dengan kebijakan pembangunan nasional, pembangunan karakter serta pembangunan bangsa yang tidak dapat terpisahkan.

Banyak masyarakat di Indonesia yang tidak mengetahui arti penting dari Pancasila. Karena tidak semua orang memahami dan mempelajari pancasila yang terdapat dalam mata pelajaran Pendidikan Kewarganegaraan dengan baik. Maka dalam kenyataannya hal tersebut akan menjadi sebuah tantangan yang dapat menghambat pengimplementasian Pancasila. Hal tersebut dapat kita cegah dengan menanamkan nilainilai dasar dari Pancasila terhadap masyarakat agar dapat memhami mengenai arti penting dari Pancasila.

Nilai-nilai Pancasila merupakan sebuah pendorong agar bangsa Indonesia dapat menegakkan serta dapat memperjuagkan kemerdekaan (Rachmah, 2013). Sehingga dengan adanya hal tersebut menjadi sebuah bukti bahwa nilai-nilai yang terkandung dalam Pancasila dapat mempermudah serta menjadi petunjuk bagi bangsa Indonesia. Kelima nilai tersebut memiliki sifat yang universal. Artinya bahwa Pancasila dapat jalankan atau di gunnakan oleh negara lain. Serta Pancasila juga memiliki sifat yang subjektif dengan memilki arti bahwa nilai yang ada dalam Pancasila sudah melekat terhadap pembawa serta adanya pendukung Pancasila sendiri diantaranya adalah masyarakat atau warga negara Indonesia, bangsa dan negara Indonesia.

Pancasila sudah menjadi landasan yang mendasar serta mengandung motivasi mengenai pedoman atau landasan dari semua perbuatan dalam kehidupan sehari-hari maupun dalam ketatanegaraan (Asmaroini, 2016). Selain itu dalam sistem kenegaraan, Peraturan perundang-undangan yang berlaku di Indonesia harus memiliki 
635 Implementasi Nilai Dasar Pancasila Dalam Upaya Mewujudkan Tujuan Negara di Kehidupan SehariHari-Mila Andriani Nurcahya, Dinie Anggraeni Dewi

DOI: https://doi.org/10.31004/edukatif.v3i3.411

hal yang sesuai dengan nilai-nilai pancasila. Adanya hal tersebut, maka dalam bentuk peraturan yang akan dapat menuntun masyarakat harus sejalan dengan nilai-nilai pancasila.

Pancasila memiliki nilai-nilai yang akan sangat bermanfaat bagi kehidupan sehari-hari. Nilai-nilai tersebut diantaranya adalah:

1. Ketuhanan Yang Maha Esa

Nilai yang terkandung pada sila pertama yaitu mengandung nilai bahwa tujuan dari manusia yang merupakan makhluk dari Tuhan Yang Maha Esa. Semua pelaksanaan dalam penyelenggaraan negara, politik negara, serta peraturan hukum perundang-undangan harus berlandaskan terhadap nilai-nilai Ketuhanan Yang Maha Esa. Sehingga dalam pelaksanaannya akan selalu aman dan tentram.

2. Kemanusiann yang Adil dan Beradab

Pada sila kedua, nilai yang terkandung dalam sila ini akan menjunjung tinggi nilai serta harkat martabat manusia sebagai makhluk tuhan yang beradap. Selain itu dalam sila kedua juga mengandung nilai dari suatu kesadaran moral serta tingkah laku manusia yang didasarkan kepada nilai serta norma dari kebudayaan yang berlaku. Baik itu terhadap diri sendiri, kepada orang lain maunpun kepada lingkungannya,

3. Persatuan Indonesia

Sila yang ketiga ini memiliki nilai yang terkandung yaitu manusia yang merupakan makhluk ciptaan tuhan yang maha esa sebagai makhluk yang monodualis. Makhluk monodulais ini manusia bisa hidup sebagai makhluk yang individu juga makhluk sosial. Namun dalam kehidupan manusia tidak dapat hidup sendiri karena stiap manusia membutuhkan orang lain. Serta di Indonesia memiliki banyak keberagaman serta perbedaan pada suku, agama, ras serta budayanya. Namun, hal tersebut kita harus bersatu dalam keanekaragaman dan tidak boleh dijadikan sebagai alasan.

4. Kerakyatan yang Dipimpin oleh Hikmat Kebijaksanan dalam Permusyawaratan atau Perwakilan

Pada sila ke empat nilai yang terkandung harus dilakukan dan dilaksanakan oleh semua masyarakat yaitu nilai demokrasi. Karena negara Indonesia merupakan sebuah negara demokrasi yang pelaksanaan pemerintahannya bersumber dari rakyat, oleh rakyat dan juga untuk rakyat sehingga rakyat atau masyarakat dapat berperan penting dalam kehidupan pemerintahan Indonesia.

5. Keadilan Sosial bagi Seluruh Rakyat Indonesia

Nilai keadilan pada sila kelima haruslah terwujud dalam semua keadilan yang ada di kehidupan ini. Pertama adalah keadilan distributive yaitu keadilan yang merupakan hubungan antra negara dan masyarakat dari negara tersebut. Kedua, keadilan legal merupakan hubungan dalam keadilan antara warga negara terhadap negaranya. Serta yang ketiga adalah keadilan komutatif yatu hubungan antara keadilan warga negara dengan lainnya.

Setelah kita memahami dari nilai yang ada atau terkandung dalam pancasila, hal tersebut dapat digunakan sebagai landasan serta pedoman dalam mengamalkannya dalam kehidupan sehari-hari. Dengan kita melakukan pengamalan dari nilai pancasila dengan sesuai maka akan mengurangi tantangan yang akan meleburkan Pancasila (Wicaksono, 2015). Karena setelah masyarakat mengerti menganao arti penting pancasila maka mereka akan menjauhi semua hal yang bertentangan dengan norma.

Nilai serta karakter dari bangsa Indonesia bersumber dari cerminan nilai-nilai Pancasila. Sehingga dalam pelaksanaannya warga Indonesia diharapkan dapat sejalan dengan nilai yang terkandung dalam pancasila (Wiyono, 2013). Diantaranya nilai tersebut adalah toleransi antar umat beragama dan beribadah sesuai agama yang dipeluknya. Kemudian memiliki kecintaan terhadap sesame manusia dan memiliki sikap yang jujur serta adil. Mempunya rasa nasionalisme atau rasa cinta kepada tanah air yaitu bangsa Indonesia serta tidak membeda-bedakan terhadap perbedaan yang kita miliki. Selain itu apabila sedang bermusyawarah diharapkan dalat menjungjung nilai-nilai yang demokrasi sehingga akan menghasilkan hasil musyawarah yang mufakat. Serta yang paling utama adalah kita harus dapat bersikap adil. 
636 Implementasi Nilai Dasar Pancasila Dalam Upaya Mewujudkan Tujuan Negara di Kehidupan Sehari-

Hari-Mila Andriani Nurcahya, Dinie Anggraeni Dewi

DOI: https://doi.org/10.31004/edukatif.v3i3.411

Setelah mengetahui bagaimana nilai yang terkandung dalam Pancasila. Diharapkan kita dapat mengamalkan atau mengimplementasikan ke dalam kehidupan sehari-hari. Agar yang telah dipelajari dapat memiliki manfaat dan dapat dijadikan sebagai pedoman kehidupan kita. Namun, sebelum itu hendaknya kita mempelajari nilai-nilai tersebut dan mengetahui bagaimana cara mengamalannya. Sehingga dengan begitu kita tidak akan salah dalam penyampaiannya.

Dalam mengimplementasikan Pancasila harus datang dari disi sendiri serta berarti bahwa Pancasila memiliki sebuah kebutuhan dalam pegangang dalam kehidupan yang berbangsa serta bernegara (Soeprapto, 2016). Dalam kondisi tersebut, tidak dapat muncul dengan sendirinya melainkan perlu adanya upaya yang dapat memunculkan kebutuhan tersebut. Agar tidak menimbulkan perpecahan dalam pengimplementasian Pancasila maka harus terdapat pegangan yang akan mengikat seluruh komponen masayakat. Perpecahan diantaranya masyarakat akan mengalami penolakan oleh kompenen yang lain dan tidak akan terjadi karena kita telah memahami nilai dari pancasila. Salah satu prinsip dapat mengikat komponen tersebut merupakan prinsip yang memiliki kemampuan dalam adanya keanekaragaman komponen bangsa serta prinsip tersebut merupakan Pancasila. Dan dalam Pancasila mampu menampung semua keberagaman sehingga tidak akan timbul perpecahan baik itu internal maupun eksternal.

Agar dapat memperkuat dalam kesadaran serta menumbuhkan keyakinan terhadap kebutuhan menganai Pancasila. Karena Pancasila merupakan pengikat dalam persatuan serta kesatuan Indonesia. Dengan tujuan mengantarkan bangsa Indonesia menuju kesejahteraan. Sehingga diperlukan beberapa upaya yang akan membuat pemahaman yang mendalam terhadap prinsip-prinsip yang terkandung dalam Pancasila. Salah satunya adalah kita harus memahami arti yang terdapat dalam Pancasila. Sehingga, ketika kita telah memahami dalam Pancasila maka akan memudahkan kita dalam mengamalkannya dengan baik.

(Zabda, 2017) menyatakan bahwa implementasi pancasila diantaranya adalah:

1. Sila Pertama : Ketuhanan Yang Maha Esa

Salah satunya yaitu dengan mengamalkan ibadah dari agama yang dianutnya. Seperti dalam agama islam mengajarkan kita untuk senantia beribadah kepada Allah SWT dengan kita melaksanakan semua yang diperintahnya dan menjauhi serta meninggalkan larangannya. Selain beribadah, bisa dilakukan dengan cara saling menghormati serta menghargai agama yang lainnya. Agar memiliki kerukunan antar umat beragama yang baik di Indonesia.

2. Sila Kedua : Kemanusiaan Yang Adil dan Beradab

Implementasi yang bisa kita lakukan diantaranya dengan menjalankan sebuah kegiatan yang didasari dengan nilai-nilai kejujuran. Karena dengan kita bersifat jujur maka kita akan memiliki sifat yang adil dengan begitu implementasi dari sila yang kedua ini akan terwujud. Selain itu sila kemanusian ini juga dapat diimplementasikan kedalam bentuk yang akan membuat sebuah perilaku yang akan saling menghargai dan menghormati martabat manusia serta kesamaan dalam hukum. Sehingga dengan begitu akan tercipta sebuah keadilan karena semuanya memiliki kesamaan tanpa membedakan suku, ras, agama dan budayanya.

3. Sila Kegita : Persatuan Indonesia

Dalam sila ketiga ini dapat diwujudkan dan diimplementasikan dalam bentuk sebuah persatuan dan kebersamaan mengenai masyarakat Indonesia. Serta dalam sila ketiga juga dijelaskan tidak adanya diskriminasi individua atau diskriminasi antar golongan. Selain itu dalam sila kegita juga diharapkan tiap masyarakat dapat memiliki rasa dalam sebuah bentuk kerjasam dan gotong royong, rela berkorban serta selalu menciptkan kehidupan yang rukun. Serta memiliki rasa nasionalisme yang sangat tinggi merupakan hal yang paling utama. Rasa nasionalisme tersebut dapat kita lakukan dengan mencintai produk dalam negeri dan memajukan UMKM yang ada di Indonesia. Sehingga dengan begitu masyarakat Indonesia dapat memiliki sebuah kemajuan dalam hal ekonomi 
637 Implementasi Nilai Dasar Pancasila Dalam Upaya Mewujudkan Tujuan Negara di Kehidupan SehariHari - Mila Andriani Nurcahya, Dinie Anggraeni Dewi

DOI: https://doi.org/10.31004/edukatif.v3i3.411

4. Sila Keempat : Kerakyatan yang Dipimpin oleh Hikmat Kebijaksanan dalam Permusyawaratan/Perwakilan

Pada sila keempat ini dapat kita wujudkan salah satunya dalam bentuk menyelesaikan permsalahan secara mufakat. Atau setiap anggota yang mengikuti msyawarah tersebut dapat mengeluarkan pendapatnya dengan demokrasi. Karena Indonesia termasuk negara yang demokrasi. Maka dalam berpendapat boleh dikeluarkan apa saja melainkan tidak menyimpang dari topik yang sedang dibahas. Serta dalam sila keempat ini juga tidak boleh ada pihak yang memaksakan kehendak pribadinya karena dalam sila ini lebih menekankan terhadap sikap yang menunjung nilai-nilai kebersamaan.

5. Sila Kelima : Keadilan Sosial Bagi Seluruh Rakyat Indonesia

Pada sila kelima dapat diimplementasikan dan juga diwujudkan dalam perilaku yang dapat menghargai hak berikut juga kewajiban dari orang lain. Selain itu, hak akan kita dapatkan harus dijalankan kewajibannya agar pelaksanaan tersebut dapat sehinggang dan tidak berat sebelah. Sehingga akan tercipta kehidupan yang adil dan juga rukun serta nyaman.

Selain yang disebutkan diatas banyak juga hal-hal yang dapat diwujudkan atau dilakukan dalam kehidupan sehari-hari. Serta tidak hanya dapat dilakukan di sekolah atau universitas saja melainkan hal tersebut dapat dilakukan dan diwujudkan dikalangan masyarakat. Sehingga perwujudan pancasila dapat meluas dan dapat dijadikan sebagai percotohan agar masyarakat Indonesia dapat berkembang semakin maju.

Dalam mewujudkan nilai-nilai yang terkandung dalam pancasila terdapat beberapa tantangan yang dapat memperlambat implementasi pancasila. Pada perkembangan zaman yang sangat signifikan saat ini, serta kecanggihan teknologi yang sudah sangat bagus akan membuat masyarakat menjadi lupa dari nilai-nilai yang terkandung dalam pancasila, Karena salah satu dari dampak tersbeut adalah masyarakat banyak yang lebih memilih untuk hidup individualis. Sehingga dengan adanya hal tersebut akan bertentangan dengan nilai yang terkandung dalam pancasila. Karena nilai yang terkandung dalam pancasila itu masyarakat Indonesia merupakan individu yang bersosial karena merupakan makhluk sosial, sehingga tidak akan dapat hidup sendiri.

Lain halnya dengan adanya globalisasi saat ini akan membuat masyarakat Indonesia menjadi berubah. Mulai dari tatanan dunia yang berubah hingga perubahan yang ada di dalam bangsanya. Perubahan tersebut merupakan sebuah tantangan karena akan memudarkan rasa nasionalisme dari bangsa Indonesia. Sehingga masyarakat Indonesia memiliki sebuah kewajiban dalam meningkatkan rasa nasionalisme dan ketahanan dalam mental ideologi bangsa yaitu pancasila. Hal tersebut disebabkan karena dengan kita memiliki kekuatan terhadap ideologi yang kita pegang yaitu pancasila maka tidak akan tergantikan dan tergeser dari ideologi yang lain.

Masyarakat Indonesia harus memiliki kemampuan dalam menghadapi tantangan yang akan muncul berdatangan. Baik itu tantangan dari dalam atau pun tantangan dari luar. Tantangan tersebut akan mengancam berbagai kehidupan mulai dari sosial, budayam politik, hingga mental bangsa Indonesia (Asmaroini, 2016). Maka dengan adanya hal tersebut, kita seharusnya memiliki keyakinan bahwa adanya dasar negara dan ideologi negara yaitu pancasila maka akan menjadi benteng agar tantangan yang ada tidak sepenuhnya terjadi. dan dengan adanya tantangan tersebut dapat dijadikan sebagai peluang dalam meningkatkan kemjauan bangsa Indonesia.

Setiap perilaku, kegiatan sehari-hari, gerakan ide, serta pola aktivitas haruslah bercermin kepada Pancasila. Karena Pancasila merupakan sumber motivasi dan juga inspirasi serta pedoman dalam berperilaku dan standar pembenarannya. Maka dengan adanya tantangan dari globalisasi ini dapat diajadikan sebagai momentum perubahan yang akan menjadikan bangsa Indonesia menjadi lebih maju. Dan diharapkan dapat membawakan perubahan dalam kehidupan keseharian masyarakat Indonesia. Selain itu dengan berpegang teguh terhadap pancasila dalam menghadapi tantangan yang ada juga akan meningkatkan masayarakat Indonesia dalam mewujudkan rasa nasionalisme Indonesia.

Maka dengan begitu beberapa tantangan yang ada dan muncul di Indonesia dengan asalnya akan menggantikan ideologi dan dasar negara yaitu pancasila tidak akan terjadi. Melainkan, dengan adanya 
638 Implementasi Nilai Dasar Pancasila Dalam Upaya Mewujudkan Tujuan Negara di Kehidupan SehariHari-Mila Andriani Nurcahya, Dinie Anggraeni Dewi

DOI: https://doi.org/10.31004/edukatif.v3i3.411

tantangan tersebut dapat dijadikan sebagai tolak ukur bahwa Indonesia akan menjadi bagian dari arus globalisasi dunia. Sehingga harus kita ingat bahwa bangsa Indonesia tidak akan kehilangan identitas bangsanya yaitu pancasila yang merupakan dampak dari adanya globalisasi.

Penerapan agar implementasi Pancasila agar dapat terlaksana dengan baik dan dapat terhindar dari beberapa tantangan yang muncul (Damanhuri et al., 2016) menyatakan bahwa penerapannya dalam silam pertama merupakan peningkatan dalam keutamaan spiritualisme. Pada sila kedua yaitu memberikan sebuah pemahaman agar dapat menghilangkan sebuah sikap yang tidak baik seperti dehumanisasi atau perbuatan yang tidak terpuji. Pada sila ketiga yaitu meningkatkan serta memperkuat mengenai kebersamaan dalam gotong royong seperti dalam azas keluarga. Sila keempat yaitu meningkatkan pemahaman masyarakat mengenai pencegahan konflik yang ada dalam masyarakat. Serta sila kelima yaitu meningkatkan pemahaman masyarakat dalam memiliki sebuah keadilan agar tidak terjadi kesalahpahaman .

Selain hal diatas agar Pancasila dapat kita implementasikan dengan baik maka kita dapat meningkatkan kuliatas diri diri. Serta sesuai dengan nilai-nilai yang terkandung dalam pancasila. Menurut (SUGIANTO et al., 2019) beberapa hal yang harus dimiliki oleh warga negara Indonesia agar dapat mengatasi tantangan dalam pengimplementasian pancasila diantaranya adalah sebagai berikut:

1. Meningkatkan kemampuan professional yang tinggi

Adanya perkembangan teknologi yang sangat pesat ini mengharuskan kita untuk memiliki kemampuan yang professional. Karena dengan seseorang memiliki kemampuan professional yang tinggi maka memiliki sebuah keahlian di bidangnya masing-masing. Sehingga dengan memiliki kemampuan tersebut maka akan meminimalisir tantangan yang terjadi saat ini.

2. Cinta tanah air

Dengan Kita mempuanyai sebuah rasa nasionasilme atau cinta tanah air yang tinggi serta mendalam maka akan memberikan sebuah motivasi yang kuat untuk berjuang. Sehingga dengan memiliki rasa cinta tanah air yang tinggi (nasionalisme) maka akan dapat berjuang dalam menghadapi tantangan yang terjadi saat ini. Selain itu pengaruh globalisasi juga sangat banyak. Agar Pancasila tetap menjadi ideologi bangsa Indonesia maka kita harus mempunyai sifat tersebut. Karena dengan kita memiliki landasan yang kuat maka tantangan tidak dapat kita cegah.

Selain dua hal diatas kita juga dapat meningkatkan iman serta ketaqwaan. Dengan tujuan agar kita tidak terjerumus dalam tindakan yang bertentangan dan tidak sesuai dengan norma. satu hal lagi agar kebudayaan yang ada di Indonesia tidak meluntur dan tetap lestari maka kita harus bertoleransi dengan budaya yang lainnya. Serta kita juga harus memperdalam kebudyaan yang kita miliki agar tidak terpengaruh oleh adanya kebudayan bangsa lain. Sehingga dengan begitu kebudayaan yang ada di Indonesia akan tetap lestari dan tidak akan luntur akibat kebudayaan lain yang datang ke Indonesia.

\section{KESIMPULAN}

Pancasila merupakan dasar negara dengan memiliki banyak nilai dasar yang dapat amalkan dalam upaya mewujudkan tujuan bangsa di kehidupan sehari-hari. Serta dalam Panacasila tersebut memiliki banyak manfaat apabila diwujudkan atau diimplementasikan dalam kehidupan. Tetapi sebelum mengamalakannya kita dianjutkan untuk memahami Pancasila itu agar dapat paham sehingga akan muncul dorongan dari dalam diri untuk mengamalkan pancasila. Meskipun terdapat banyak tantangan dalam pengamalannya hal tersebut jangan kita jadikan beban melainkan jadikan sebagai sebuah penyemangat agar bangsa Indonesia ini dapat berkembang dengan pesat.

\section{DAFTAR PUSTAKA}

Akbal, M. (2016). Pendidikan Kewarganegaraan dalam Pembangunan Karakter Bangsa. Gadjah Mada University Press Bekerjasama Dengan LAN RI., 1(1), 485-493. 
639 Implementasi Nilai Dasar Pancasila Dalam Upaya Mewujudkan Tujuan Negara di Kehidupan SehariHari - Mila Andriani Nurcahya, Dinie Anggraeni Dewi

DOI: https://doi.org/10.31004/edukatif.v3i3.411

Asmaroini, A. P. (2016). Implementasi Nilai-Nilai Pancasila Bagi Siswa Di Era Globalisasi. Citizenship Jurnal Pancasila Dan Kewarganegaraan, 4(2), 440. https://doi.org/10.25273/citizenship.v4i2.1077

Asshiddiqie, J. (2010). Konstitusi dan Konstitusionalisme Indonesia. Sinar Grafika.

Bo’a, F. Y. (2017). Pancasila Dalam Sistem Hukum. Pustaka Pelajar.

Damanhuri, D., Bahrudin, F. A., Legiani, W. H., \& Rahman, I. N. (2016). Implementasi Nilai-Nilai Pancasila Sebagai Upaya Pembangunan Karakter Bangsa. Untirta Civic Education Journal, 1(2), 185-198. https://doi.org/10.30870/ucej.v1i2.1890

Darmadi, H. (2020). Apa Mengapa Bagaimana Pembelajaran Pendidikan Moral Pancasila dan Pendidikan Pancasila dan Kewarganegaraan. An1mage.

Dewantara, A. (2018). Pancasila dan Multikulturalisme Indonesia. 109-126. https://doi.org/10.31227/osf.io/8r7h9

Harefa, A. (2011). Implementasi Pancasila Sebagai Dasar Filsafat Dalam Kehidupan Berbangsa Dan Bernegara. Didaktik, 5(2), 437-451.

Rachmah, H. (2013). Nilai-Nilai Dalam Pendidikan Karakter Bangsa Yang. E-Jurnal Widya Non-Eksakta, 1.

Situru, R. S. (2019). Pancasila dan Tantangan Masa Kini. Elementariyjurnal, 2(1), 34-41.

Soeprapto. (2016). Implementasi Pancasila Dalam Kehidupan Ber Masyarakat Berbangsa Dan Bernegara. Jurnal Ketahanan Nasional, 10(2), 7-14.

SUGIANTO, B., TAENA, L., \& BILU, L. (2019). Implementasi Pancasila Tantangan Dan Solusinya. Gema Pendidikan, 26(2), 10. https://doi.org/10.36709/gapend.v26i2.8175

Wicaksono, R. (2015). Implementasi Nilai-Nilai Pancasila Di Era Reformasi Dalam Mencegah Berkembangnya Tindak Radikalisme. JURNAL POLINTER: KAJIAN POLITIK DAN HUBUNGAN INTERNASIONAL, 1(2).

Wiyono, S. (2013). Reaktualisasi Pancasila dalam Kehidupan Berbangsa dan Bernegara. Universitas Wisnuwardhana Malang Press.

Zabda, S. (2017). Aktuali sasi Nilai-nilai Pancasila sebagai Dasar Falsafah Negara dan Implementasinya Dalam Pembangunan Karater Bangsa. Jurnal Pendidikan Ilmu Sosial, 26(2), 106-114. 